\title{
RESEARCH PAPER \\ Growth analysis of potted gerbera conducted with mineral fertilization and organic fertigation
}

\author{
Francielly T. dos Santos ${ }^{1}$, Fernanda Ludwig ${ }^{2}$, Luiz A. de M. Costa1 ${ }^{1}$, Mônica \\ S. S. de M. Costa ${ }^{1}$, Marcelo B. Remor ${ }^{1}$, and Plínio E. R. Silva ${ }^{1}$ \\ 'Pós-graduação em Engenharia Agrícola (PGEAGRI), Centro de Ciências Exatas e Tecnológicas, \\ Universidade Estadual do Oeste do Paraná, R. Universitária, 1619, CEP 85819-110, Cascavel, Paraná, Brazil. \\ ${ }^{2}$ Universidade Estadual do Rio Grande do Sul, A. Independência, 2824, CEP 96816-501, Santa Cruz do Sul, \\ Rio Grande do Sul, Brazil.
}

\begin{abstract}
F.T. Santos, F. Ludwig, L.A.M. Costa, M.S.S.M. Costa, M.B. Remor, and P.E.R. Silva. 2016. Potted gerbera growth analysis conducted with mineral fertilization and organic fertigation. Chile. Cien. Inv. Agr. 43(1):111-120. Potted gerbera is an ornamental plant that is widely commercialized in Brazilian markets. However, information on cultivation techniques is needed to meet growing demand, especially with regard to fertilization. This study was carried out to assess the growth of potted gerbera, Florist Red Black cultivar, with mineral and organic fertilization. The experiment was conducted in a greenhouse located at UNIOESTE - Cascavel Campus - PR. The experimental design was composed of randomized blocks with four replicates and five treatments. Treatments were defined according to the fertilization source, which were mineral (NPK) and organic. Organic fertilizers were obtained by diluting in water four organic composts from agroindustrial-waste composting processes. After obtaining composts, water dilution was performed, adjusting the nutritive solution electrical conductivity values. Gerbera plants were assessed fortnightly $(0,14,28,42$, and 56 days after acclimatization) for leaf area and shoot dry matter, which were adjusted for time using the ANACRES program to obtain the leaf area ratio (LAR), relative growth rate (RGR), and net assimilation rate (NAR). Fifty-six days after acclimatization, plants were assessed for number of leaves, plant diameter, leaf area, leaves and inflorescences dry phytomass, stem height, head diameter, and stem diameter. The highest relative growth rates were obtained in plants grown with organic compost in treatment 3. However, the net assimilation rate, which indicates dry matter conversion efficiency, was highest in plants with chemical fertilization (treatment 1).
\end{abstract}

Key words: Agroindustry residues, Gerbera jamesonii, net assimilation rate.

\section{Introduction}

Gerbera (Gerbera jamesonii) belongs to the Asteraceae family and is originally from southern

Received April 18, 2015. Accepted February 26, 2016. Corresponding author: francielly_torres@hotmail.com
Africa and Asia (Gao and Hind, 2011). It is a perennial and herbaceous plant with composite flowers. In nature, gerbera is found in colors including yellow, dark orange, white, pink, red, carmine, and even violet (Cardoso and Silva, 2013). Leaves are arranged in a rosette shape, and the petiole of some of them grows floral buds that 
develop peduncles with terminal inflorescence in the head (INFOAGRO, 2015).

In recent years, potted and cut gerbera commercial cultivation has gained great economic importance for floriculture (Santos et al., 2015). Despite its expanding commercial production, research has not kept pace, with little information on cultivation, especially with regard to nutrition and fertilization (Ludwig et al., 2010a). As a result, fertilizers used by farmers are derived from companies' techniques empirical observations (Ludwig et al., 2010b; Muniz et al., 2013). Pesticide use has increased due to high pest incidence in culture (Cardoso and Silva, 2013).

Flower cultivation is carried out predominantly with chemical fertilizers as opposed to organic fertilization, which is derived from organic residues. This is mainly due to the reduced cycle of potted crops and the nutrients provided by readily available mineral fertilization (Castro et al., 2010; Beckmann-Cavalcante et al., 2010). However, there is a growing interest among producers and consumers for the production of alternative forms that are less harmful to the environment, necessitating the development of studies regarding organic nutrition.

Agroindustrial and agricultural activities are responsible for large amounts of waste generation. An interesting alternative for recycling and a better use of solid organic waste is composting, which is an aerobic decomposition process that converts the residues into relatively stable humic substances (Primo et al., 2010). The challenges of finding a destination for the generated residues along with producing quality flowers at competitive prices have generated interest in research for this approach (Castro et al. 2010).

Typically, organic fertilizers' nutrient concentrations are higher than those of mineral fertilizers due to higher nutrient diversity (Primo et al., 2010), which may result in toxicity and thus impair ornamental plant development when not managed correctly.
Electrical conductivity (EC) indicates the amount of ionized salts in the material (Beckmann-Cavalcante et al., 2013), and for gerbera culture, Oldoni (2009) indicated optimal values between 1.5 and $2.0 \mathrm{dS}$ $\mathrm{m}^{-1}$ provided by fertigation, and suggested that higher values affect culture development. Thus, in addition to determining substrate solution salts concentration, it is important to monitor plant development by growth analysis.

Plant growth parameters, such as leaf area ratio (LAR), net assimilation rate (NAR), and relative growth rate (RGR), can be expressed through growth analysis technique (Ludwig et al., 2010a, Farias and Saad, 2011). This analysis describes plant morphophysiological conditions at different time intervals and allows for tracking of photosynthetic production dynamics, which are measured by dry matter mass accumulation (Farias and Saad, 2011). Growth analysis also allows inferring physiological activity, that is, precisely estimating growth variation causes between similar plants growing in different conditions, such as in different fertilizers (Benincasa, 2003).

Plant growth knowledge is fundamental to proper management and identification of problems in culture development such as water and nutritional deficiency occurrence, among others. In floriculture, where market competition is intense, productivity differences in these factors are important for appropriate management leading to satisfactory production (Mota et al., 2013).

Because growth analyses are based on the dry matter accumulated by plants during growth, this is a measure of photosynthetic activity. Growth analysis indicates the morphological and physiological conditions of a plant and assesses its net production derived from the photosynthetic process as a result of the assimilatory system during a certain period of time. This study was conducted to evaluate the growth of gerbera plants grown with mineral fertilizers and organic fertigation. 


\section{Material and methods}

The experiment was conducted in a greenhouse located at the Western Parana State University UNIOESTE, municipality of Cascavel (24⒌'01's; 5332'01'W), Paraná State, Brazil. During the experimental period, the average temperature inside was $29.5{ }^{\circ} \mathrm{C}$, and the average relative humidity was $58.5 \%$.

The greenhouse was an arch type structure, with sides covered by $150 \mu \mathrm{m}$ clear plastic, and a total area of $96.0 \mathrm{~m}^{2}$ (2.6 $\mathrm{m}$ in height). To ensure uniform light intensity and diffuse light transmission inside the greenhouse, a thermal reflector mesh (Aluminet ${ }^{\circledR}$ ) was internally settled, with $30 \%$ shading.

The experimental was composed of randomized blocks, with five treatments and four replicates of six pots per plot and one plant per pot, for a total of 30 sampling units per block and 120 in the entire experiment. Treatments were defined according to fertilization, with one mineral treatment and four organic treatments. The mineral treatment, named $\mathrm{T}_{1}$, was performed every 15 days with 5.0 $\mathrm{g}$ per pot of the 4-10-8 N-P-K formula, using 0.2 $\mathrm{g}$ of ammonium sulfate $\left(\left(\mathrm{NH}_{4}\right)_{2} \mathrm{SO}_{4}-21 \%\right.$ of $\left.\mathrm{N}\right)$; $0.4 \mathrm{~g}$ of single superphosphate $\left(\mathrm{P}_{2} \mathrm{O}_{2}-18 \%\right.$ of $\left.\mathrm{P}\right)$; $0.3 \mathrm{~g}$ of potassium chloride $(\mathrm{KCl}-61 \%$ of $\mathrm{K})$.

Liquid organic fertilizers were obtained from organic compost dilution resulting from agroindustrial waste composting processes. The initial composition (before composting) of each treatment is shown in Table 1. Each composting windrow was made with $500 \mathrm{~kg}$ (natural material) of agroindustrial wastes. Details on the composting process are described in Bernardi (2011).

At the end of the composting process, organic composts with high electrical conductivities (EC) $-5.56,8.29,3.63$, and $5.46 \mathrm{dS} \mathrm{m}^{-1}$ for $\mathrm{T}_{2}, \mathrm{~T}_{3}, \mathrm{~T}_{4}$, and $\mathrm{T}_{5}$, respectively- were generated, limiting their use as potted gerbera production substrates. Then, organic compost dilution was done to allow using
Table 1. The initial composition of agroindustrial wastes before composting of each treatment $(\mathrm{kg})$.

\begin{tabular}{lcccc}
\hline Wastes & $\mathrm{T}_{2}$ & $\mathrm{~T}_{3}$ & $\mathrm{~T}_{4}$ & $\mathrm{~T}_{5}$ \\
\hline Corn residue & 145 & 50 & 0 & 0 \\
Hatchery residue & 80 & 70 & 40 & 35 \\
Flotation sludge & 30 & 50 & 45 & 35 \\
Wheat husks & 50 & 50 & 0 & 0 \\
Cellulosic casing & 20 & 110 & 50 & 75 \\
Pig manure solid fraction & 90 & 45 & 100 & 75 \\
Boiler remaining coal & 25 & 30 & 70 & 30 \\
Boiler remaining ash & 30 & 30 & 80 & 150 \\
Truck wash residue solid fraction & 30 & 45 & 15 & 15 \\
Poultry litter & 0 & 50 & 0 & 10 \\
Sugar cane bagasse & 0 & 0 & 100 & 75 \\
\hline
\end{tabular}

only the liquid fraction through culture fertigation. After dilution, nutrient solutions were generated with EC values, in the vegetative period, of 0.56 , $0.51,0.36$, and $0.27 \mathrm{dS} \mathrm{m}^{-1}$ for $\mathrm{T}_{2}, \mathrm{~T}_{3}, \mathrm{~T}_{4}$, and $\mathrm{T}_{5}$, respectively. In the reproductive period, $\mathrm{EC}$ values were of $1.52,1.38,0.97$, and $0.73 \mathrm{dS} \mathrm{m}^{-1}$ for $\mathrm{T}_{2}$, $\mathrm{T}_{3}, \mathrm{~T}_{4}$, and $\mathrm{T}_{5}$, respectively. The $\mathrm{pH}$ values were of 5.55, 5.65, 5.55, and 5.70, for $\mathrm{T}_{2}, \mathrm{~T}_{3}, \mathrm{~T}_{4}$, and $\mathrm{T}_{5}$, respectively, in both periods.

To reach optimal dilutions of organic composts, dilution tests were performed. Dilution was based on the potassium nutrient, as it was in higher concentrations in the liquid organic fertilizers. After dilution tests, $27 \mathrm{~kg}$ of each organic compost was established and placed in $100 \mathrm{~L}$ barrels. The volume was adjusted to $100 \mathrm{~L}$ with water, and this solution was stirred by hand every day for 30 min, for 60 days. After this period, the solution was filtered and only the liquid phase, known as liquid organic fertilizers (LOFs), was used. LOFs were chemically characterized and are shown in Table 2. Total nitrogen content was quantified by Kjeldahl distiller digestion according to the methodology proposed by EMBRAPA (2009). Other macronutrients and micronutrients were also determined according to EMBRAPA (2009) methodologies.

The experimental unit consisted of a plastic pot (number 14) filled with $900 \mathrm{~mL}$ of Tropstrato HT 
Table 2. Liquid organic fertilizers (LOF) chemical composition after fertigation dilution in vegetative and reproductive periods $\left(\mathrm{mg} \mathrm{kg}^{-1}\right)$.

\begin{tabular}{|c|c|c|c|c|}
\hline & LOF 1 & LOF 2 & LOF 3 & LOF 4 \\
\hline \multicolumn{5}{|c|}{$\begin{array}{l}\text { Vegetative period } \\
\text { Macronutrients }\end{array}$} \\
\hline $\mathrm{N}$ & 7.200 .00 & 4.700 .00 & 2.400 .00 & 3.000 .00 \\
\hline $\mathrm{P}$ & 0.04 & 0.02 & 0.02 & 0.01 \\
\hline K & 105.00 & 105.00 & 105.00 & 105.00 \\
\hline $\mathrm{Ca}$ & 159.53 & 118.88 & 99.05 & 47.48 \\
\hline $\mathrm{Mg}$ & 25.78 & 14.80 & 19.00 & 15.51 \\
\hline \multicolumn{5}{|c|}{ Micronutrients } \\
\hline $\mathrm{Na}$ & 59.27 & 51.10 & 120.18 & 30.81 \\
\hline $\mathrm{Cu}$ & 0.19 & 0.01 & 0.04 & 0.05 \\
\hline $\mathrm{Fe}$ & 20.07 & 17.08 & 11.50 & 5.72 \\
\hline $\mathrm{Mn}$ & 0.32 & 0.63 & 0.03 & 0.08 \\
\hline $\mathrm{Zn}$ & 0.71 & 0.68 & 1.29 & 0.15 \\
\hline \multicolumn{5}{|c|}{$\begin{array}{l}\text { Reproductive period } \\
\text { Macronutrients }\end{array}$} \\
\hline $\mathrm{N}$ & 23.000 .00 & 21.600 .00 & 13.500 .00 & 14.700 .00 \\
\hline $\mathrm{P}$ & 0.11 & 0.09 & 0.13 & 0.08 \\
\hline K & 285.00 & 285.00 & 285.00 & 285.00 \\
\hline $\mathrm{Ca}$ & 432.79 & 542.68 & 538.61 & 260.27 \\
\hline $\mathrm{Mg}$ & 70.08 & 67.57 & 82.26 & 84.85 \\
\hline \multicolumn{5}{|c|}{ Micronutrients } \\
\hline $\mathrm{Na}$ & 160.79 & 233.28 & 653.45 & 168.55 \\
\hline $\mathrm{Cu}$ & 0.51 & 0.05 & 0.23 & 0.30 \\
\hline $\mathrm{Fe}$ & 54.45 & 77.90 & 67.83 & 31.31 \\
\hline $\mathrm{Mn}$ & 0.87 & 2.91 & 0.17 & 0.44 \\
\hline $\mathrm{Zn}$ & 1.93 & 3.11 & 7.04 & 0.86 \\
\hline
\end{tabular}

Agroindustrial Residues Laboratory (LARA), UNIOESTE, Cascavel, Brazil.

hortaliças commercial substrate. This commercial substrate consists of pine bark, peat and vermiculite, fertilized with single superphosphate and potassium nitrate, as indicated by the manufacturer. Substrate chemical characteristics are: EC $0.5 \mathrm{dS} \mathrm{m}^{-1}$ and pH 5.8 (Brasil, 2007); macronutrients $\left(\mathrm{g} \mathrm{kg}^{-1}\right)$ : N 0.06; P 0.001; K 0.06; $\mathrm{Ca} 0.55$; and $\mathrm{Mg} 0.28$; and micronutrients (mg kg${ }^{-1}$ ): $\mathrm{Na} 575.47 ; \mathrm{Cu} 0.27 ; \mathrm{Fe}$ 275.27; Mn 3.587; and Zn 4.08 (EMBRAPA, 2009). Substrate physical characteristics as provided by the manufacturer are as follows: $60 \%$ moisture, $130 \%$ water retention capacity, wet density of $500 \mathrm{~kg} \mathrm{~m}^{-3}$.

Phytosanitary management was done organically. Every seven days, Bordeaux mixture was applied for fungi prevention and horn-manure (500) and horn-silica (501) biodynamic preparations were also used. Biodynamic preparation 500 was applied after transplantation and 501 after transplantation and also at the end of the vegetative period. Biodynamic preparation use was not characterized as a variable response because it was used in all treatments to ensure plant phytosanitary management.

The horn-silica biodynamic preparation (501), or "light preparation", was applied to the plants twice in the crop cycle, during transplantation and at the end of the vegetative period.

Gerbera seedlings (G. jamesonii) from Florist Red Black cultivar were used, acquired in Ball ${ }^{\circledR}$ 
Horticultural do Brasil Ltda. company trays. Seedlings had four mature leaves at transplant and were acclimated for 15 days while irrigating with water only. After this period, mineral fertilization and organic fertigation began.

Mineral treatment irrigation and organic treatment fertigation were carried out based on pots daily weighing, taking daily evaporation into account. Pots were maintained with $70 \%$ of the water retention capacity of the vegetative period and $80 \%$ in the reproductive period. Substrate available water maximum amount was set based on the substrate water retention capacity, which was measured from 10 pot weighings per block. Irrigation and fertigation were manually performed using graduated recipients with an average of 120 $\mathrm{mL}$ pot $^{-1}$ day $^{-1}$.

Pots were arranged on wooden tables without spacing. After leaves overlapped, pots were spaced at $0.20 \times 0.20 \mathrm{~m}$. Experimental assessment was initiated after 15-day acclimatization, and the results were expressed in days after acclimatization (DAA).

The leaf area and plants' dry phytomass were determined every 14 days, at $0,14,28,42$, and 56 DAA. The plant shoot part was cut at the substrate, and leaf area was determined using a Li-Cor 3100 Leaf Area Meter; the results were expressed in $\mathrm{cm}^{2}$. Plant shoots, separated in the reproductive period into leaves and inflorescence, were dried in a forced ventilation oven at $65{ }^{\circ} \mathrm{C}$ until a constant weight was achieved; total dry phytomass was obtained with a digital scale. To obtain leaf area ratio (LAR), relative growth rate (RGR), and net assimilation rate (NAR) physiological indexes, total dry matter and leaf area variables were adjusted in relation to time $(0,14,28,42$, and 56 DAA) using the ANACRES program (Portes and Castro Junior, 1991) and the quadratic exponential equation. After obtaining the parameters calculated by ANACRES, data were subjected to analysis of variance to see if there were any treatment significant effects. For average analyses, Tukey's test showed no significance. However, Fisher test scores indicated significance at the $5 \%$ level. The data variables LAR, RGR, and NAR presented normality and homogeneity of variance with $5 \%$ significance, according to the Shapiro-Wilk and Levene tests, respectively.

At 56 DAA, number of leaves (NL), plant diameter (PD), leaf area (LA), leaves dry matter (LDM), inflorescences dry matter (IDM), stem height (SH), head diameter (HD), and stem diameter (SD) were determined. PD was determined using a ruler graduated in millimeters, adopting two extreme points that were perpendicular to each other, according to the methodology proposed by Ludwig et al. (2010b). LDM and the IDM were obtained after drying in an oven at $65{ }^{\circ} \mathrm{C}$ with forced air circulation until a constant weight was obtained. SH was measured using a ruler graduated in millimeters from the pot upper portion to below the inflorescence insertion. HD and SD were measured with a digital caliper, with SD being measured at $5.0 \mathrm{~cm}$ below the inflorescence insertion.

Initially, exploratory data analysis was performed and analysis of variance assumptions were verified. Later, data were subjected to analysis of variance to see if there were any significant treatment effects. When there was significance, Tukey's test at a 5\% significance threshold was applied to compare means.

\section{Results and discussion}

All growth results from having enough material production to meet existing material metabolic needs and also to store or build new material (Benincasa, 2003). Thus, the relative growth rate (RGR) can be regarded as a performance index, representing the plant's ability to generate new structures (Cavatte et al., 2012).

RGR levels decreased over the experiment (Figure 1), in agreement with the results obtained by Ludwig 
et al. (2010a), who assessed growth of Red and Cherry gerbera cultivars. According to Ferrari et al. (2008), with the addition of accumulated dry matter in plants, there is an increase in photoassimilate needs for the maintenance of already existing structures, decreasing available amounts for growth, thus justifying RGR decreases. According to Benincasa (2003), RGR-value decreases over the cycle are common to most species and are related to the decrease in the net assimilation rate (NAR) and leaf area ratio (LAR). Factors such as self-shading, lower leaf area increment over the cycle and increased respiratory activity also contribute to RGR reduction during development (Braga et al., 2010).

Negative RGR, observed at 56 DAA, except for $\mathrm{T}_{1}$, indicates the plants entered senescence (Figure 1). T1 showed higher biomass production during the cycle, thus exhibiting more effective biomass conversion. As LAR values for this treatment were lower (Figure 2), it is possible to infer that its growth is directly related to NAR due to its higher net photosynthesis rate (Figure 3).

From a marketing standpoint, gerbera plants fertigated with liquid organic fertilizers for 56 days have already lost quality due to entering the senescence period. In this case, to ensure the same durability in relation to fertilization, the sampling point must be anticipated.

The leaf area ratio (LAR) represents useful leaf area for photosynthesis and is the ratio between the area responsible for trapping light energy and $\mathrm{CO}_{2}$ and the total dry matter (Benincasa, 2003). Thus, the highest values at the beginning of the cycle indicate that the plant has a higher leaf area to be used in photosynthesis and converted into growth. At this time, the plant converts higher photoassimilate amounts to leaf expansion, aimed at capturing light. Throughout the cycle, the useful leaf area for photosynthesis decreases (Figure 2), as gerbera has rosette growth and leaves overlap, resulting in shading of the upper on the lower (Ludwig et al., 2010a).
Similar results were observed by Aumonde et al. (2011), who concluded that the decrease in LAR values is related to the gradual reduction in photoassimilate volumes translocated to mini watermelon leaves. Oliveira et al. (2008), while studying melon, found that this rate reached the maximum value in approximately 25 days because at this stage the plant has many leaves and tender branches with little dry matter.

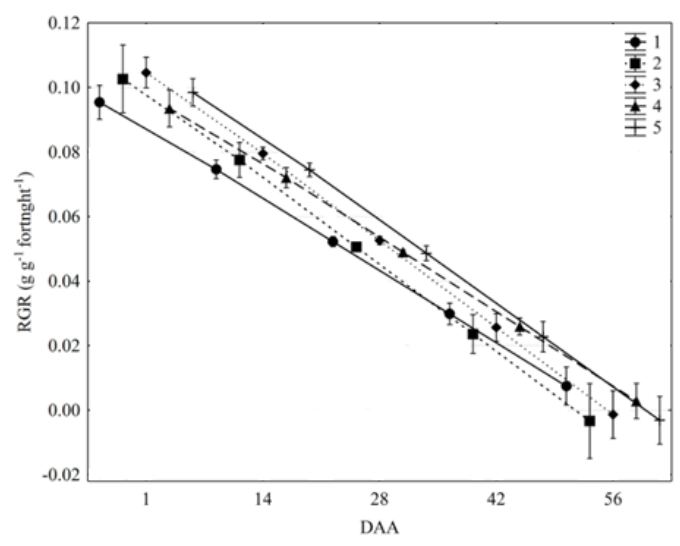

Figure 1. Relative growth rate mean values in gerbera plants treated with mineral and organic fertilization during the days after acclimatization. Cascavel, UNIOESTE. 2014. RGR: Relative growth rate; DAA: days after acclimatization. 1: $\mathrm{T}_{1}$ commercial substrate: mineral fertilization (NPP), irrigated with water. 2: T2 composition. 3: T3 composition. 4: T4 composition. 5: T5 composition.

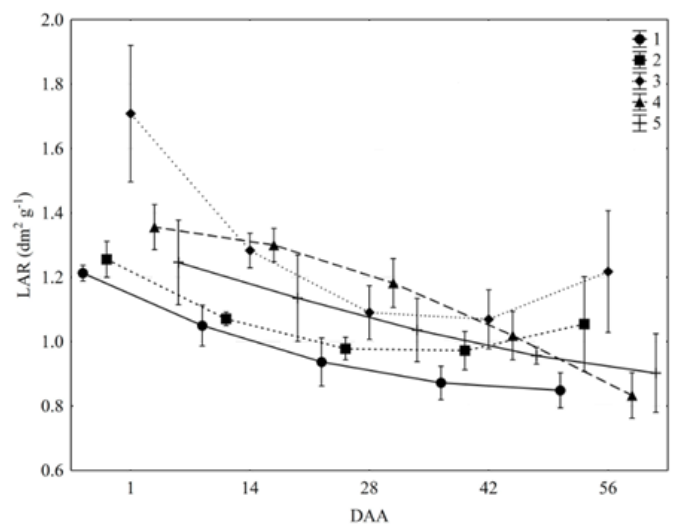

Figure 2. Leaf area ratio mean values in gerbera plants treated with mineral and organic fertilization during the days after acclimatization. Cascavel, UNIOESTE. 2014. LAR: Leaf area ratio; DAA: days after acclimatization. 1: $\mathrm{T}_{1}$ commercial substrate: mineral fertilization (NPP), irrigated with water. 2 : $\mathrm{T}_{2}$ composition. $3: \mathrm{T}_{3}$ composition. 4: $\mathrm{T}_{4}$ composition. 5: $\mathrm{T}_{5}$ composition. 
Treatments were statistically significant according to the analysis of variance (P-value 0.0049). The highest LAR was observed for $\mathrm{T}_{3}(\mathrm{P} \leq 0.05)$ and the lowest for $\mathrm{T}_{1}$ (Figure 2). In plants from $\mathrm{T}_{3}$, the leaf area increased by $8.2 \mathrm{dm}^{2}$ over the cycle, resulting in $7.3 \mathrm{~g}$ of increased dry matter. While in $T_{1}$, the leaf area increased $6.2 \mathrm{dm}^{2}$, and dry matter increased $7.7 \mathrm{~g}$, i.e., it was more efficient at converting light energy and $\mathrm{CO}_{2}$ to biomass production. Although the useful leaf area for photosynthesis was higher in $\mathrm{T}_{3}$, it was not effectively harnessed to produce more leaf and inflorescence dry matter (Table 3 ). The lowest final LAR was found in $\mathrm{T}_{4}$ (Figure 2). In this treatment, the leaf area increased 5.9 $\mathrm{dm}^{2}$, while the dry matter increased by $7.4 \mathrm{~g}$. Although there was not a high leaf area increase, the photosynthetically active area was very efficient, as dry mass considerably increased. This may have occurred because leaves were thicker in this treatment (Table 3).

Brachmann-Cavalcante et al. (2013) found that the largest LAR values corresponded to chrysanthemums plants treated with an EC of $2.1 \mathrm{dS} \mathrm{m}^{-1}$, regardless of assessment time, a result confirmed by its having the highest dry matter of both shoot and total, as well as a larger leaf area. On the other hand, the EC $2.5 \mathrm{dS} \mathrm{m}^{-1}$ treatment, which did not differ statistically from the EC of $2.1 \mathrm{dS} \mathrm{m}^{-1}$ in the aforementioned variables, had the lowest LAR until 28 DAA, matching the treatment with EC $2.1 \mathrm{dS} \mathrm{m}^{-1}$ only at $56 \mathrm{DAA}$. This LAR decrease in the treatment with EC $2.5 \mathrm{dS} \mathrm{m}^{-1}$ may be due to higher leaf efficiency in converting light energy and $\mathrm{CO}_{2}$ into dry matter.

The net assimilation rate (NAR) is the balance between the material produced by photosynthesis and the material lost by respiration (Dartora et al., 2013), indicating leaf efficiency in biomass production. Similar to other indexes, values are reduced during the cycle (Figure 3) due to selfshadowing and increased respiration for plant maintenance.

It was observed that NAR values were higher for $\mathrm{T}_{1}$ (56 DAA) $(\mathrm{P} \leq 0.05)$ (Figure 3$)$. This physiological index demonstrates the reduced leaf area efficiency in producing dry biomass of both leaves and inflorescences (Table 3). Low values for this physiological index were observed in plants conducted with $\mathrm{T}_{3}$, indicating that higher RGR values for this treatment are directly related to NAR.

The highest relative growth rates were obtained in plants with organic compost on T3. However, the net assimilation rate, which indicates dry matter conversion efficiency, was higher in the $\mathrm{T}_{1}$ plants with mineral fertilization.

Table 3. Number of leaves (NL), plant diameter (PD), leaf area (LA), leaves dry matter (LDM), inflorescence dry matter (IDM), stem height (SH), head diameter (HD), and stem diameter (SD) in gerbera plants grown in mineral fertilizer and liquid organic fertilization, obtained at 56 DAA.

\begin{tabular}{lcccccccc}
\hline & NL & PD & LA & LDM & IDM & SH & HD & SD \\
\cline { 2 - 8 } & & $(\mathrm{cm})$ & $\left(\mathrm{cm}^{2}\right)$ & $(\mathrm{g})$ & $(\mathrm{g})$ & $(\mathrm{cm})$ & $(\mathrm{mm})$ & $(\mathrm{mm})$ \\
\hline $\mathrm{T}_{1}$ & 15.00 & 18.02 & 683.91 & 8.23 & 6.97 & $17.55 \mathrm{~b}$ & 86.07 & 4.44 \\
$\mathrm{~T}_{2}$ & 18.25 & 18.70 & 674.67 & 7.25 & 7.35 & $22.20 \mathrm{a}$ & 82.90 & 4.46 \\
$\mathrm{~T}_{3}$ & 20.00 & 18.62 & 893.51 & 7.78 & 6.65 & $20.32 \mathrm{ab}$ & 88.42 & 4.54 \\
$\mathrm{~T}_{4}$ & 23.25 & 19.27 & 663.65 & 8.02 & 7.17 & $18.02 \mathrm{~b}$ & 90.42 & 4.52 \\
$\mathrm{~T}_{5}$ & 17.25 & 19.85 & 594.95 & 6.60 & 7.44 & $23.30 \mathrm{a}$ & 79.90 & 4.43 \\
$\mathrm{CV}(\%)$ & 21.76 & 8.70 & 25.41 & 11.28 & 11.89 & 6.89 & 7.24 & 6.43 \\
\hline
\end{tabular}

Means followed by the same letter in the column do not differ by Tukey's test at a 5\% significance level. DAA: Days after acclimatization. 1: $\mathrm{T}_{1}$ commercial substrate: mineral fertilization (NPP), irrigated with water. 2: $\mathrm{T}_{2}$ composition. $3: \mathrm{T}_{3}$ composition. 4: $\mathrm{T}_{4}$ composition. 5: $\mathrm{T}_{5}$ composition. 


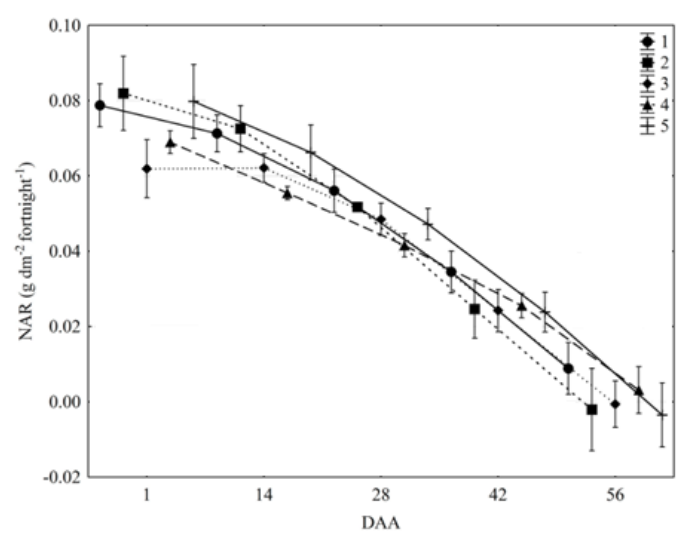

Figure 3. Net assimilation rate mean values in gerbera plants treated with mineral and organic fertilization during the days after acclimatization. Cascavel, UNIOESTE. 2014. NAR: Net assimilation rate; DAA: days after acclimatization. 1: $\mathrm{T}_{1}$ commercial substrate: mineral fertilization (NPP), irrigated with water. 2: $\mathrm{T}_{2}$ composition. 3: $\mathrm{T}_{3}$ composition. 4: $\mathrm{T}_{4}$ composition. 5: $\mathrm{T}_{5}$ composition.

\section{Acknowledgment}

We thank the Agricultural Engineering Graduate Program (PGEAGRI/UNIOESTE, Brazil) for the opportunity to conduct this research, and CAPES for granting a Masters Scholarship in support of this work.

\section{Resumen}

F.T. Santos, F. Ludwig, L.A.M. Costa, M.S.S.M. Costa, M.B. Remor y P.E.R. Silva. 2016. El análisis del crecimiento de gerbera en maceta realizada con la fertilización mineral y orgánica fertirrigación. Chile. Cien. Inv. Agr. 43(1):111-120. La gerbera es una planta ornamental que es ampliamente comercializada en el mercado brasileño. Sin embargo, para satisfacer la creciente demanda, es necesario contar información sobre las técnicas de cultivo, destacando la fertilización. Este trabajo se realizó con el fin de evaluar el crecimiento de gerbera en maceta, cultivar Floristería Rojo Negro, fertilizado con un producto mineral y fertilización orgánica. El experimento se realizó en un invernadero ubicado en UNIOESTE - Cascavel Campus - PR. El diseño experimental fue de bloques al azar, con cuatro tratamientos y cinco repeticiones. Los tratamientos se definieron de acuerdo a la fuente de la fertilización mineral (NPP) y orgánico. La fertilización orgánica se obtuvo diluyendo cuatro compuestos orgánicos de proceso de compostaje de residuos agroindustriales en agua. Después de la obtención de estos compuestos, se ajustaron los valores de conductividad eléctrica de la solución nutritiva. En las plantas de gerbera se evaluó cada dos semanas $(0,14,28,42$ y 56 días después de la aclimatación), el área foliar y la materia seca, que se ajusta en relación con el tiempo con el programa ANACRES, con el fin de obtener la relación de área foliar (LAR), tasa de crecimiento relativo (RGR) y la tasa de asimilación neta (NAR). 56 días después de la aclimatación, se evaluó en el número de hojas, diámetro de la planta, área foliar, hojas e inflorescencias de fitomasa seca, altura de tallo, diámetro de la cabeza y el diámetro del tallo. Las mayores tasas de crecimiento relativo se obtuvieron en plantas realizados con abono orgánico en el tratamiento 3. Sin embargo, la tasa de asimilación neta, que indica la eficiencia de conversión de materia seca, fue mayor en las plantas con la fertilización química, en el tratamiento 1.

Palabras clave: Gerbera jamesonii, residuos agroindustriales, tasa de asimilación neta. 


\section{References}

Aumonde, T.Z., N.F. Lopes, D.M. Moraes, R.M.N. Peil, and T. Pedó. 2011. Análise de crescimento do híbrido de mini melância Smile $\AA$ enxertada e não enxertada. Interciência 36:677-681.

Beckmann-Cavalcante, M. Z., K.F.L. Pivetta, I.H.L. Cavalcante, L.F. Cavalcante, P.A. Bellingieri, and M.C.C. Campos. 2010. Condutividade elétrica da solução nutritiva para o cultivo do crisântemo em vaso. Revista Brasileira de Ciência do Solo 34:747-756.

Beckmann-Cavalcante, M. Z, K.F.L. Pivetta, I.H.L. Cavalcante, L.F. Cavalcante, and J.V.S. Silva Júnior. 2013. Nutritional status of the potted chrysanthemum relative to electrical condutivity and salt leaching. Revista Ciência Agronômica 44:782-789.

Benincasa, M.M.P. 2003. Análise de Crescimento de Plantas: Noções Básicas. $2^{\circ}$ ed. Jaboticabal, FUNEP. 42 pp.

Bernardi, F.H. Compostagem de resíduos agroindustriais. 2011. Dissertação (Mestrado em Engenharia Agrícola) - Centro de Ciências Exatas e Tecnológicas, Universidade Estadual do Oeste do Paraná, Cascavel.

Braga, C. de L., D. M Fernandes, L. F. Sirtoli, and F Ludwig. 2010. Análise de crescimento de girassol ornamental de vaso e aplicação de nitrogênio. Scientia Agraria Paranaensis 9:52-59.

Brasil. 2007. Instrução Normativa n.17, de 21 de maio de 2007. Aprova os Métodos Analíticos Oficiais para Análise de Substratos e Condicionadores de Solos. Diário Oficial da União, Brasília. Seção 1. p. 8.

Cardoso, J.C., and J.A.T. Silva. 2013. Gerbera micropropagation. Biotechnology Advances 31:1344-1357.

Castro, A.M.C., O. Sato, K.H. Santos, R.A. Zapolli, S.B. Sartori, and G.B. Demétrio. 2010. Adubação mineral e orgânica no desenvolvimento de crisântemo. Semina: Ciências Agrárias 31:93100.

Cavatte, P.C., N.F. Rodriguez-López, S.C.V. Martins, M.S. Mattos, L.M.V.P. Sanglard, and F.M. Damatta. 2012. Functional analysis of the relative growth rate, chemical composition, construction and maintenance costs, and the payback time of Coffea arabica L. leaves in response to light and water availability. Journal of Experimental Botany 63:3071-3082.

Dartora, J., F. Guimarães, M.M. Echer, D.R. Pauletti, and D. Marini. 2013. Análise de crescimento e produtividade do pak choi cultivado sob diferentes doses de nitrogênio. Revista Ceres 60:498504.

EMBRAPA. 2009. Manual de análises químicas de solos, plantas e fertilizantes. Empresa Brasileira de Pesquisa Agropecuária. 2. ed. Brasília, DF. $309 \mathrm{pp}$.

Farias, M.F., and J.C.C. Saad. 2011. Análise de crescimento de vaso, cultivar Puritan, irrigado em diferentes tensões de água em ambientes protegidos. Revista Acta Scientiarum Agronomy 133:75-79.

Ferrari, T.B., G. Ferreira, V. Zucareli, and C.S.F. Boaro. 2008. Efeito de reguladores vegetais nos índices da análise de crescimento de plântulas de maracujazeiro-doce (Passiflora alata Curtis). Biotemas 21:45-51.

Gao, T., and D.J.N. Hind. 2011. Gerbera Linnaeus. Flora China 20:13-21.

INFOAGRO. 2015. El cultivo de la gerbera. Available online at: http:/www.infoagro.com/flores/ flores/gerbera.htm (Website accessed: February 02, 2015).

Ludwig, F., A.C. Guerrero, D.M. Fernandes, and R.L. Villas Boas. 2010a. Análise de crescimento de gérbera de vaso conduzida em diferentes substratos. Revista Horticultura Brasileira 28:70-74.

Ludwig, F., D.M. Fernandes, P.R.D. Mota and R.L. Villas Bôas. 2010b. Crescimento e produção de gérbera fertirrigada com solução nutritiva. 2010b. Revista Horticultura Brasileira 28:424429.

Mota, P.R.D., A.C.R. Fiorim, R.L. Villas Bôas, M.V. Folegatti, F. Ludwig, and M.E.A. Silva. 2013. Condutividade elétrica da solução nutritiva e acúmulo de macro e micronutriente no cultivo de crisântemo. Bragantia 72:81-89.

Muniz, M.A., J.G. Barbosa, G.P. Garde, and C.M.L. Alves. 2013. Produção e qualidade de gérbera 
de corte submetidas a diferentes doses de potássio e épocas de colheita. Horticultura Brasileira 31:582-586.

Oldoni, C.M. Produção de gérberas. 2009. Informe agropecuário 30:67-73.

Oliveira, F.A., J.F. Medeiros, C.J.G. Lima, I. Dutra, and M.K.T. Oliveira. 2008. Crescimento do meloeiro Gália fertirrigado com diferentes doses de nitrogênio e potássio. Caatinga 21:168-173.

Portes, T.A., and L.G. Castro Junior. 1991. Análise de crescimento de plantas: Um programa compu- tacional auxiliar. Revista Brasileira de Fisiologia Vegetal 3:53-56.

Primo, D.C., F.S. Fadigas, J.C.R. Carvalho, C.D.S. Schimidt, and A.C.S. Borges. 2010. Avaliação da qualidade nutricional de composto orgânico produzido com resíduos de fumo. Revista Brasileira de Engenharia Agrícola e Ambiental 14:742-746.

Santos, F.T., F. Ludwig, L.A.M. Costa, and M.S.S.M. Costa. 2015. Nutrition and growth of potted gerbera according to mineral and organic fertilizer. Ornamental Horticulture 21:251-258. 